\title{
Beliefs about Human-Nature Relationships and Implications for Investment and Stewardship Surrounding Land-Water System Conservation
}

\author{
John D. Coley ${ }^{1,2, *(\mathbb{D}) \text {, Nicole Betz }}{ }^{1,3}$, Brian Helmuth ${ }^{1,4,5}$, Keith Ellenbogen 1,6 , Steven B. Scyphers ${ }^{1,4}$ \\ and Daniel Adams 1,7 \\ 1 Cognitive Laboratory of Environmental and Arts Research (CLEAR), Northeastern University, \\ Boston, MA 02115, USA; nicole.betz@yale.edu (N.B.); b.helmuth@northeastern.edu (B.H.); \\ kellenbogen@gmail.com (K.E.); s.scyphers@northeastern.edu (S.B.S.); da.adams@northeastern.edu (D.A.) \\ 2 Department of Psychology, Northeastern University, Boston, MA 02115, USA \\ 3 Department of Psychology, Yale University, New Haven, CT 06510, USA \\ 4 Department of Marine and Environmental Sciences, Northeastern University, Nahant, MA 01908, USA \\ 5 School of Public Policy and Urban Affairs, Northeastern University, Nahant, MA 01908, USA \\ 6 Department of Photography, SUNY The Fashion Institute of Technology, New York, NY 10001, USA \\ School of Architecture, Northeastern University, Boston, MA 02115, USA \\ * Correspondence: j.coley@northeastern.edu; Tel.: +1-617-373-3548
}

check for updates

Citation: Coley, J.D.; Betz, N.; Helmuth, B.; Ellenbogen, K.; Scyphers, S.B.; Adams, D. Beliefs about Human-Nature Relationships and Implications for Investment and Stewardship Surrounding Land-Water System Conservation. Land 2021, 10, 1293. https://doi.org/ 10.3390/land10121293

Academic Editors: Moira Zellner and Juan Carlos Castilla-Rho

Received: 24 October 2021

Accepted: 22 November 2021

Published: 25 November 2021

Publisher's Note: MDPI stays neutral with regard to jurisdictional claims in published maps and institutional affiliations.

Copyright: (c) 2021 by the authors. Licensee MDPI, Basel, Switzerland. This article is an open access article distributed under the terms and conditions of the Creative Commons Attribution (CC BY) license (https:// creativecommons.org/licenses/by/ $4.0 /)$

\begin{abstract}
When engaging stakeholders in environmental conservation, it is critical to understand not only their group-level needs, but also the individually held beliefs that contribute to each person's decisions to endorse or reject policies. To this end, we examined the extent to which people conceptualize the interconnected relationship between humans and nature in the context of a hypothetical urban waterway, and the implications thereof for environmental investment and stewardship. We also explored how these beliefs varied based on describing the waterway as having either local or global impacts, and as originating either naturally or through artificial processes. Three hundred and seventy-nine adults from the United States read vignettes about a polluted urban waterway and thereafter reported their investment in river clean-up, their stewardship of the river, and their beliefs surrounding human-nature relationships. Results revealed a common belief pattern whereby humans were believed to impact the urban river disproportionately more than the river impacts humans, suggesting that lay adults often weigh the impacts of humans on the natural world disproportionally. Critically, this disproportionate pattern of thinking inversely predicted investment of time and money in river clean-up. Results also revealed a potential solution to this psychological bias: highlighting local benefits of the waterway decreased the asymmetry of the human-nature relationship. We discuss the psychological factors contributing to this cognitive bias, and the implications of these findings on stakeholder engagement.
\end{abstract}

Keywords: stakeholder engagement; pro-environmentalism; human exceptionalism; ecological connectedness; psychological distance

\section{Introduction}

Sustainable and equitable solutions to the persistent and accelerating threats posed by climate change and habitat destruction require effective stakeholder engagement and public support [1,2]. To accomplish these goals, and especially to do so in ways that are equitable and ensure that diverse voices are included in the discussion, we need to better understand how to attract and engage with participants who may come to the table with diverse, and sometimes conflicting, perceptions and priorities. A central question is, how do we encourage affected individuals to prioritize the conservation of their local ecosystems within the larger context of global climate change? Lessons from cognitive psychology offer an opportunity to explore how people consider the interconnections 
between human behaviors and land/water systems, and how these conceptualizations might predict levels of investment and stewardship [3]. In this study we examine the extent to which people's conceptualizations of their environment and their place within (or separate from) social-ecological systems can serve as a predictor of how connected people feel to nature, and, subsequently, their willingness to be involved in conservation and stewardship in the context of land-river systems. We further explore whether framing descriptions of land-river systems as local or global phenomena, and as natural or artificial waterways, impacts both the conceptualization and commitment to conservation of these social-ecological systems.

A large body of literature has shown that when communicating with stakeholders, it is important to understand the needs, biases, priorities, and perceptions of the group(s) of people with which one is working $[4,5]$. Such an understanding can also play an important role in ensuring that decisions are equitable and consider the views of vulnerable and underserved populations, which can differ from those of the majority population [6]. For example, people who live on the "hidden coast" (non-ocean-front properties frequently occupied by minority and socioeconomically disadvantaged communities) are usually neglected when developing coastal adaptation strategies [7]. However, though demographic information, such as race, socioeconomic status, political affiliation, or home ownership, can provide valuable insights into group-level perceptions of climate risk and their willingness to act, at best these correlations provide only guideposts. Ultimately, a person's attitudes and behaviors are driven by the complex interplay of societal norms and lived experiences, and therefore vary from person to person, especially in individualistic cultures characteristic of Western societies [8].

Cognitive psychology techniques can help to untangle these influences by investigating mental processes, such as cognitive biases, that can stem from an individuals' unique experiences that shape their beliefs about conservation. This includes understanding stakeholders' perceptions of risk and their priorities for addressing threats [9], as well as how they think about relevant social-ecological relationships [10]. In the context of environmental management or policies [11], one understudied factor that may influence stakeholder engagement is how a person considers their own relationship to nature (e.g., [12]), and, specifically, the degree to which they consider themselves as part of a coupled human-natural system, as opposed to being apart from nature and the services it provides.

Engaging stakeholders in planning and management through approaches such as community science can bolster the success of environmental initiatives [13-15]. However, stakeholder engagement is challenging, and many projects fail to move beyond planning stages. Often described as the "planning-implementation gap" in conservation, scientists and practitioners have argued that greater emphasis and application of cognitive frameworks is needed to improve communication, integrate multiple sources of knowledge, and promote shared ownership of the prevailing issue and initiatives [16,17]. Below, we discuss two potentially relevant cognitive frameworks for these purposes: ecological connectedness and human exceptionalism.

\subsection{Human Exceptionalism and Ecological Connectedness}

Cognitive research demonstrates that humans possess powerful intuitive frameworks that provide efficient, but often fallible, guidelines for dealing with complex concepts (e.g., [18-21]), such as land-water systems (e.g., [22]). Of particular relevance for conceptualizing social-ecological systems are the intuitive ways that people conceptualize the relationship between humans and the environment [12]. Two of these intuitive frameworks have been consistently linked to environmental engagement: human exceptionalism and connectedness to nature.

Human exceptionalism is the belief that humans are qualitatively distinct and separate from all other forms of life, as well as from natural systems, and/or the belief that natural and biological laws do not apply to humans [23-25]. Though humans may have 
many unique abilities (e.g., advanced technologies and complex language), exceptionalist thinking can nevertheless be deleterious for scientific understanding when overextended. Indeed, human exceptionalist beliefs have been associated with misunderstanding ecosystem processes [26], and reduced concerns about climate change impacts [27,28].

Whereas human exceptionalism describes a perceived separation between humans and the natural world, ecological connectedness describes perceptions of human/nature interrelatedness [29-31]. Most often, this has been assessed in terms of feeling personally connected with nature [32]. Individuals who have a personal connection with nature are more likely to engage in pro-environmental behaviors [33], feel more concerned about environmental issues, such as global climate change [34], and display other pro-environmental behaviors and attitudes. Among other factors, feeling more connected to nature can stem from frequent or meaningful nature experiences (e.g., [35]), or physical proximity to natural environments, such as living on the coast [36]. With modern comforts providing extensive indoor spaces and built environments, individuals have become increasingly distanced from the natural world, impacting how they conceptualize human-nature relationships, such as ecological connectedness [12,37].

\subsection{Psychological Distance}

Another potential factor impacting beliefs and attitudes about land-water systems could be psychological distance. Psychological distance is the subjective distance between one's immediate experience and representations of other experiences separated in time and/or space [38,39]; this perceived distance may facilitate or inhibit feelings of connection to ecosystems. There is increasing interest in understanding psychological distance through the scales at which information and solutions are presented to stakeholders (e.g., local vs. global), including debate over the effectiveness of "proximizing" the impacts of global climate change [40-42]. One approach to studying this issue is through manipulations of framing $[43,44]$. Presumably, framing an issue in terms of local consequences reduces the psychological distance between the reader and the issue, thereby increasing engagement. However, the results to date have not been straightforward [40], and can vary with the characteristics of the particular audience (e.g., [45]). In some cases, framing environmental issues in local terms increases sustainable attitudes and behaviors (e.g., [46,47]), whereas in others, local framing has no effect (e.g., $[48,49])$. One explanation for the inconsistent results may be failure to consider underlying cognitive mechanisms; proximizing might be expected to have more impact on beliefs and mental representations than on attitudes and motivations [40].

Another way to conceptualize psychological distance is by direct analogy to physical distance. In other words, when investigating beliefs and attitudes about ecological issues at the land-water interface, people who live closer to bodies of water may feel less psychological distance to such issues because of the physical proximity and, therefore, personal relevance of such issues. As with the literature on local framing cited above, results seem complex. For example, New Zealand residents living closer to a shoreline expressed greater belief that climate change is real, and greater support for government regulation of carbon emissions [50]. In a sample of landowners living in the Johnson Creek Watershed in Oregon, proximity to water was most strongly related to economic support for water resource protection (via taxes, fees, or fines), rather than to general pro-water attitudes (e.g., the importance of protecting lakes and streams [51]). In contrast, though proximity to wetlands was associated with increased knowledge of wetlands in a national US sample, it was unrelated to concern for wetlands ecosystem services or conservation involvement [52].

In the present study, we examine the impact of psychological distance on beliefs about exceptionalism and connectedness, as well as support for environmental investment and stewardship. We do so both by manipulating global (i.e., more psychologically distant) versus local (i.e., more psychologically proximal) framing, and by asking participants to report their physical proximity to a body of water. 


\subsection{The Current Study}

Rivers and waterways support a wide variety of benefits for people, including recreation (swimming, fishing, etc.) and access to drinking water [53]. Yet, especially in urban environments [54], benefits such as these are often underappreciated [55,56]. For example, though an urban resident may regularly travel to a rural environment for recreation in "nature", they may fail to recognize the value of waterways in their own neighborhood [57]. Moreover, as communities adapt to climate change using a range of artificial ("gray") and living ("green") infrastructure [58,59], there is considerable interest in understanding people's perceptions of, and preference for, gray and green adaptation solutions $[15,60,61]$. This conceptualization of nature as primarily "distant" can have spillover effects on a person's willingness to engage in local activities, and their willingness to invest in the protection or recovery of local ecosystems. In this paper, we explore the potential influence of human exceptionalism and connectedness to nature on people's willingness to invest in the preservation and restoration of urban waterways. We address three specific research questions about relations among social-ecological beliefs (i.e., human exceptionalism and ecological connectedness), investment, and stewardship: (1) What do people believe about the relationship between humans and urban waterways? (2) How are beliefs related to environmental investment or stewardship? (3) How does framing influence beliefs, investment, and stewardship?

\section{Materials and Methods}

Participants read a brief scenario about a hypothetical polluted river that ran through an urban area. The river was described as either artificial or natural, and the ability of the waterway and surrounding wetlands to filter pollution and nutrients from the city was described as benefitting either local or global regions. Participants then answered a series of questions to assess their tendencies toward environmental investment and environmental stewardship, and their beliefs about human exceptionalism and ecological connectedness in the context of the hypothetical urban waterway.

\subsection{Participants}

Participants all resided in the USA ( $N=379,156$ female, 222 male, 1 undisclosed gender; Age $M=37.46, S D=12.00$; Range 19-78) and were recruited through the online platform Amazon Mechanical Turk. On average, participants reported left-leaning fiscal and social political beliefs (see Supplementary Materials). All participants were fluent English speakers. All participants gave their informed consent for inclusion before they participated in the study. The study was conducted in accordance with the Declaration of Helsinki, and the protocol was approved by the Institutional Review Board of Northeastern University (IRB\# 18-04-20).

\subsection{Materials}

\subsubsection{Manipulation: River Vignettes}

Our manipulation featured short vignettes that described a small river located in a city. Vignette content varied by two orthogonal dimensions: natural/artificial and local/global impacts, resulting in four target vignette types: natural/local, natural/global, artificial/local, and artificial/global. In addition, we had a control vignette that did not contain language affiliated with these dimensions. The "natural" river was described as pre-existing the city, whereas the "artificial" river was described as man-made with the intention of funneling the city's runoff. The "local" impact of the river and its surrounding wetlands was the function of serving as a drainage system that removes waste from the city, whereas the global impact was the function of filtering the city's polluted run-off water before the water enters the ocean. All vignettes ended with "The local, state, and federal government will all need to make significant investments in the river to restore the ecosystem and therefore fix this issue". 
Target vignette variants had similar word lengths (219-227 words), whereas the control vignette was shorter (115 words). See Table 1 for sample language manipulated across vignettes, and Supplementary Materials for full examples of all vignettes. To increase the tangibility of the river in the story, we also included the same image of a river within a city: a picture of the Muddy River in Boston alongside each vignette.

Table 1. Sample content manipulated across vignettes.

\begin{tabular}{|c|c|}
\hline Condition & Relevant Content \\
\hline Natural & $\begin{array}{l}\text { Today, there is a natural river flowing through a city. The river was there long } \\
\text { before people established the city. In the } 1880 \text { s, the city began to connect its } \\
\text { drainage systems to the river. }\end{array}$ \\
\hline Artificial & $\begin{array}{l}\text { Today, there is a manmade river of water flowing through a city. The river was } \\
\text { built by people who established the city. In the 1880s, the city was rapidly } \\
\text { developing and all the water from around the city was funneled to create this } \\
\text { new river. }\end{array}$ \\
\hline Local & $\begin{array}{l}\text { But, the river remains a local resource because the river serves as a drainage } \\
\text { system that takes run-off away from the city into the nearby lake ... In this way, } \\
\text { the river benefits the local life of the city. }\end{array}$ \\
\hline Global & $\begin{array}{l}\text { But, the river remains a global resource because the river filters water run-off } \\
\text { from the city before the water enters into the nearby ocean } . . . \text { In this way, the } \\
\text { river benefits all areas connected to the ocean. }\end{array}$ \\
\hline
\end{tabular}

\subsubsection{Measures}

As described in Table 2, participants completed measures assessing environmental investment, environmental stewardship, beliefs about human exceptionalism, and beliefs about ecological connectedness.

Table 2. Summary of Study Measures.

\begin{tabular}{|c|c|c|c|}
\hline Question Type & Target Construct(s) & Question & Scale \\
\hline \multirow[t]{2}{*}{ Investment } & $\begin{array}{l}\text { Amount of Government } \\
\text { Investment }\end{array}$ & $\begin{array}{l}\text { A full restoration of the river would cost } \$ 100 \\
\text { million. How many tax dollars do you think that } \\
\text { the different branches of government should } \\
\text { invest in river clean up? } \\
\text { - } \quad \text { Local (City) Government } \\
\text { - State Government } \\
\text { - } \quad \text { Federal Government }\end{array}$ & $\$ 0$ million to $\$ 100$ million \\
\hline & Willingness to Volunteer & $\begin{array}{l}\text { If you were a resident of the city, how many } \\
\text { hours would you be willing to spend on a } \\
\text { Saturday to volunteer to clean up the river? }\end{array}$ & $0 \mathrm{~h}$ to $12 \mathrm{~h}$ \\
\hline \multirow[t]{2}{*}{ Stewardship } & $\begin{array}{l}\text { Prioritization of } \\
\text { Programs }\end{array}$ & $\begin{array}{l}\text { What is the order in which you think that the } \\
\text { following issues should be prioritized? } \\
\text { - } \quad \text { River Cleanup Project } \\
\text { - } \quad \text { Reducing Local Property Taxes } \\
\text { - } \quad \text { Purchasing New Textbooks for } \\
\text { Elementary Schools } \\
\text { - } \quad \text { Expanding the City's Recycling Program } \\
\text { - Litter Removal from the City Streets }\end{array}$ & $\begin{array}{l}1 \text { to } 5 \text { priority rank } \\
\text { (mutually exclusive) }\end{array}$ \\
\hline & $\begin{array}{l}\text { Favorability of } \\
\text { Protective Actions }\end{array}$ & $\begin{array}{l}\text { To what extent would you be in favor of ... } \\
\text { - } \quad \text { New laws designed to protect the river } \\
\text { - Community-based initiatives to protect } \\
\text { the river }\end{array}$ & $\begin{array}{l}1 \text { ("Fully Against") to } \\
5 \text { ("Fully in Favor") }\end{array}$ \\
\hline
\end{tabular}


Table 2. Cont.

\begin{tabular}{|c|c|c|c|}
\hline Question Type & Target Construct(s) & Question & Scale \\
\hline & $\begin{array}{l}\text { Perceived Human } \\
\text { Responsibility }\end{array}$ & $\begin{array}{l}\text { To what extent do humans have a responsibility } \\
\text { to protect their surrounding ecosystems? }\end{array}$ & $\begin{array}{c}0 \text { ("None at all. They should } \\
\text { let nature run its course") to } \\
100 \text { ("Humans are fully } \\
\text { responsible") }\end{array}$ \\
\hline \multirow[t]{2}{*}{ Beliefs } & Human Exceptionalism & $\begin{array}{l}\text { To what extent do you think that ... } \\
\text { - the behaviors of people in the city impact } \\
\text { the river? } \\
\text { - the river impacts the people in the city? }\end{array}$ & $\begin{array}{c}0 \text { ("None at all") to } \\
100 \text { ("To a Great Extent") }\end{array}$ \\
\hline & $\begin{array}{l}\text { Perceived Ecological } \\
\text { Connectedness }\end{array}$ & $\begin{array}{l}\text { To what extent do you think that people are } \\
\text { ecologically connected to other living things? }\end{array}$ & $\begin{array}{l}0 \text { ("Not Connected at all") to } \\
100 \text { ("Fully Connected") }\end{array}$ \\
\hline
\end{tabular}

\subsubsection{Demographics}

Participants reported their age, gender, and political affiliation. They also rated how conservative and liberal their beliefs about fiscal and social issues are on a scale from 0 (liberal) to 100 (conservative), the rurality of the area where they live (rural, urban, suburban), and the proximity of where they live to a body of water on a scale of 0 (no bodies of water nearby) to 100 (live on a body of water).

\subsection{Design}

Participants were shown one of five vignettes about a fictitious river. The four target vignettes varied orthogonally in terms of their descriptions of the origin of the river (i.e., naturally occurring versus artificially built) and the location of pollution effects (i.e., local versus global). The control vignette contained none of these descriptors. All participants then completed all measures.

\subsection{Procedure}

Testing was done online using Qualtrics survey software (Qualtrics, Provo UT). After consenting, participants read one vignette and had to correctly answer two comprehension check questions that reaffirmed content manipulated in vignettes (for targets) or incidental content (for control vignette) to advance. All participants were then told to imagine that the river in the story was real prior to completing the measures in the order presented in Table 2. At the end of the survey, participants answered demographics questions. Participants were tested in two cohorts, one in December 2019 and one in February 2020. The vignettes, questions on which we focus here, and order of measures were identical in both cohorts. Each cohort was also asked additional unique questions not analyzed here.

\section{Results}

\subsection{What Do People Believe about the Relationship between Humans and Urban Waterways?}

One potentially relevant aspect of ecological beliefs is the degree to which humans and local waterways are perceived to impact each other. To examine these beliefs, we focused on responses to two survey questions: "To what extent do you think that the river impacts the people in the city?" (hereafter, RiH for "river impacts humans") and "To what extent do you think that the behaviors of people in the city impact the river?" (hereafter, $\mathrm{HiR}$ for "humans impact river"). Both ratings were high in absolute terms (see Table 3), and differed significantly from the midpoint (50) of the scale $(t(378)>20.71, p<0.001$, Cohen's $d>3.60$ ) indicating the general belief that there were notable impacts in both directions. Moreover, these two scores showed a strong positive correlation (Spearman's rho(379) $=0.587, p<0.001)$, suggesting that people tended to perceive both impacts as having similar magnitude. 
Table 3. Mean, standard deviation, and range for investment, stewardship and belief variables $(N=379)$.

\begin{tabular}{|c|c|c|c|c|}
\hline & Variable & Mean & Standard Deviation & Range \\
\hline \multirow{4}{*}{$\begin{array}{l}\text { Investment } \\
\text { Composite }\end{array}$} & City Government & 39.79 & 24.70 & $1-100$ \\
\hline & State Government & 40.89 & 21.12 & $0-100$ \\
\hline & Federal Government & 38.26 & 26.30 & $0-100$ \\
\hline & Volunteer Hours & 3.97 & 3.05 & $0-12$ \\
\hline \multirow{4}{*}{$\begin{array}{l}\text { Stewardship } \\
\text { Composite }\end{array}$} & Ranked Priority of River Cleanup Project & 1.91 & 1.18 & $1-5$ \\
\hline & Support for Protective Laws & 4.32 & 1.04 & $1-5$ \\
\hline & Support for Protective Community Initiatives & 4.37 & 1.07 & $1-5$ \\
\hline & Perceived Human Responsibility & 84.59 & 19.65 & $0-100$ \\
\hline \multirow{4}{*}{ Beliefs } & Human Impacts on River (HiR) & 85.70 & 17.59 & $10-100$ \\
\hline & River Impacts on Humans (RiH) & 78.85 & 21.84 & $1-100$ \\
\hline & Human Exceptionalism * & 7.04 & 18.79 & $-40-99$ \\
\hline & Ecological Connectedness & 82.22 & 19.81 & $0-100$ \\
\hline
\end{tabular}

* Note: Exceptionalism was not measured directly, but rather computed by subtracting RiH from HiR.

We looked for human exceptionalism beliefs in three ways. First, we compared HiR and $\mathrm{RiH}$ scores directly, and found that HiR scores were significantly higher, $t(378)=7.22$, $p<0.001, d=0.37$, demonstrating a belief that humans would have a disproportionate impact on the river relative to the river's perceived impact on humans.

Second, we classified participants into three groups based on the magnitude of difference between HiR and $\mathrm{RiH}$ scores. If scores were identical, we classified a participant as perceiving equal influence. If the scores differed, we classified the participant as perceiving either human > river influence or river > human influence, depending on the direction of the difference. Frequencies are presented in Table 4 . Human $>$ river was the modal response pattern $\left(X^{2}(2, N=379)=57.66, p<0.001\right)$, and more than twice as many participants rated humans impact river higher than river impacts humans.

Table 4. Frequencies for perceived impact patterns.

\begin{tabular}{ccc}
\hline Perceived Impact Pattern & Frequency & Percent of Participants \\
\hline Human $>$ River & 196 & $51.7 \%$ \\
Equal & 90 & $23.7 \%$ \\
River $>$ Human & 93 & $24.5 \%$ \\
\hline
\end{tabular}

Finally, we explored the extent to which HiR scores and RiH scores predicted ecological connectedness. A multiple regression analysis showed that both $\mathrm{HiR}$ and $\mathrm{RiH}$ beliefs were associated with connectedness beliefs $\left(R^{2}=0.362, p<0.001\right)$, but that HiR scores $(\beta=0.483$, $95 \%$ CI 0.384-0.583) were a significantly stronger predictor than $\mathrm{RiH}$ scores $(\beta=0.174$, $95 \%$ CI 0.075-0.275). In other words, beliefs about connectedness were driven by beliefs about human impact on the environment much more strongly than beliefs about the environment's impact on humans.

\subsection{How Are Beliefs Related to Environmental Investment and Stewardship?}

As detailed in Table 1, the majority of our questions can be interpreted as measures of willingness to invest (both time and money) in environmental restoration efforts, or as measures of a sense of stewardship or willingness to take responsibility for environmental restoration. A principal components factor analysis of scores on the dependent measures in Table 1 confirmed this structure. Two factors emerged, with all hypothesized stewardship measures loading on one factor, and all hypothesized investment measures loading on the other (see Table S3 of Supplementary Online Materials). Based on this analysis, we constructed a composite measure of environmental investment by averaging standardized scores for beliefs about the amount of local, state, and federal tax dollars that should be invested in restoration and volunteer hours, and another for environmental stewardship by 
averaging standardized scores for support for protective laws, support for community initiatives, belief that it is humans' responsibility to restore the river, and ranking of importance for river restoration. We also calculated individual exceptionalism scores by subtracting each participant's $\mathrm{RiH}$ score from their HiR score, yielding a measure of the difference in perceived impact, with higher scores representing more disproportional human impact. We then conducted two multiple regression analyses, in which we used exceptionalism, beliefs about connectedness, and proximity to water (as a measure of psychological distance) to predict each composite. Results are given in Table 5.

Table 5. Multiple regression models examining the degree to which beliefs about exceptionalism and connectedness, as well as reported proximity to water, predict investment and stewardship.

\begin{tabular}{ccccc}
\hline \multirow{2}{*}{ Composite Outcome Measure } & \multirow{2}{*}{$\boldsymbol{R}^{\mathbf{2}}$} & \multicolumn{3}{c}{ Standardized Coefficient Beta } \\
\cline { 3 - 5 } & & Exceptionalism & Connectedness & Proximity to Water \\
\hline Investment & $0.072^{* * *}$ & $-0.187^{* * *}$ & -0.001 & $0.187^{* * *}$ \\
Stewardship & $0.249^{* * *}$ & -0.050 & $0.496^{* * *}$ & 0.011 \\
\hline
\end{tabular}

Results differed substantially across the investment and stewardship models. Willingness to invest in river restoration (local, state, and federal tax dollars, as well as volunteer hours) was consistently associated with lower levels of exceptionalism and greater reported proximity to water, but unrelated to beliefs about connectedness. In contrast, beliefs about stewardship (i.e., that humans are responsible for protecting surrounding ecosystems, support for protective laws and community-based initiatives, and ranking river restoration as a priority) was associated with increased beliefs about connectedness, but unrelated to exceptionalism or proximity to water.

\subsection{How Does Framing an Explanation of the Waterway Impact Beliefs, Investment, and Stewardship?}

Recall that participants read a short vignette that introduced the urban river as naturally formed or artificially created, and, orthogonally, described the consequences of pollution in global or local terms. To examine the impact of this manipulation on responses, we conducted 2 (River: Natural v Artificial) $\times 2$ (Consequences: Global v Local) ANOVAs on exceptionalism, connectedness, investment, and stewardship scores. Participants showed lower exceptionalism when the vignette was framed locally $(M=4.07,95 \%$ CI 1.54-6.60) than when it was framed globally $(M=8.92,95 \%$ CI 5.59-12.25), $F(1291)=5.30, p=0.022$, $\eta^{2}=0.018$. Exceptionalism was also lower in the local condition than in the control condition (in which the river was described in neutral terms, $M=9.87,95 \%$ CI 5.36-14.38), $t(245)=2.38, p=0.018, d=0.319$, see Figure 1 . Describing the river as natural or artificial had no effect on exceptionalism.

To further explore this finding, we examined framing effects on the components of the exceptionalism index by conducting a 2 (Consequences: Global v Local) $\times 2$ (Beliefs: $\mathrm{HiR}, \mathrm{RiH}$ ) mixed ANOVA on perceived impact scores. As reported above, HiR beliefs were higher than RiH beliefs, $F(1291)=38.07, p<0.001, \eta^{2}=0.027$. We also observed a beliefs $x$ consequences interaction, $F(1291)=5.30, p=0.022, \eta^{2}=0.004$. Simple effect analysis showed that $\mathrm{RiH}$ beliefs were higher when the consequences of river pollution were presented in local terms than when they were presented in global terms $(p=0.028$, see Figure 2). Framing had no effect on HiR beliefs $(p=0.726)$. In other words, local framing reduced human exceptionalism by increasing the degree to which people believed that the urban waterway impacts humans. Framing had no direct effect on beliefs about connectedness $(p>0.510)$, stewardship $(p>0.106)$, or investment $(p>0.570)$. 


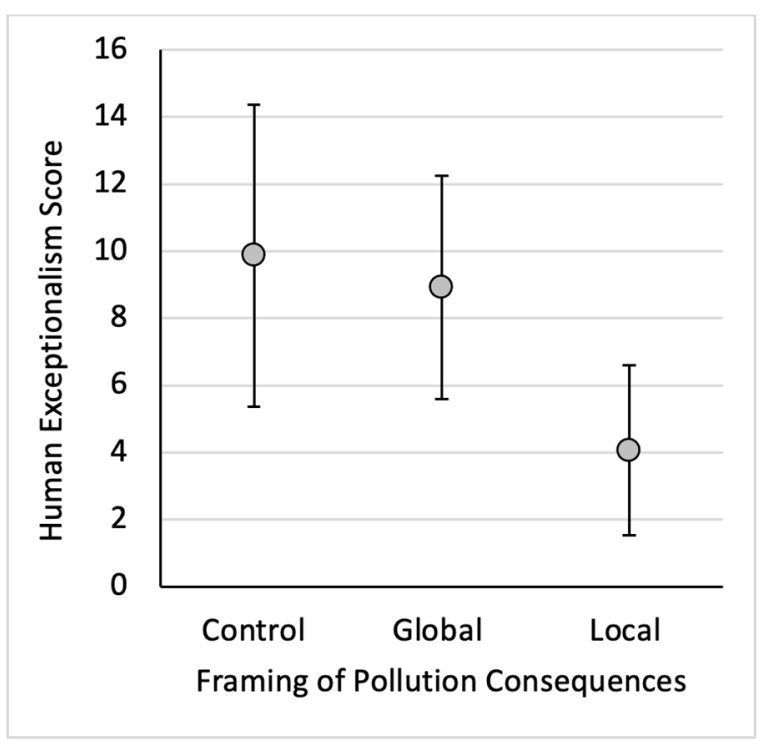

Figure 1. Mean human exceptionalism scores for participants in global framing, local framing, and control conditions. Note: error bars represent $95 \%$ confidence intervals.

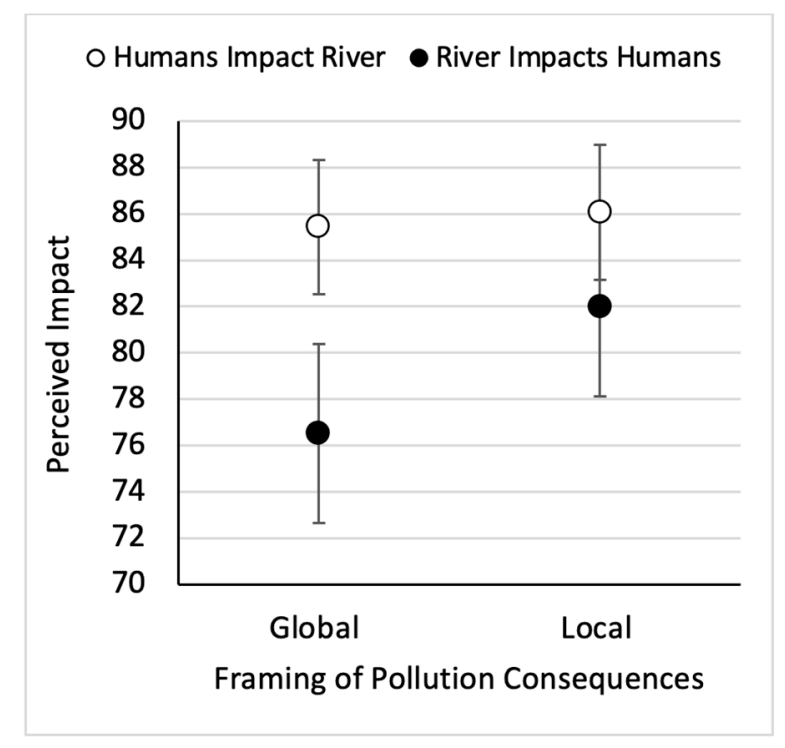

Figure 2. Mean HiR and $\mathrm{RiH}$ scores for participants in global and local framing conditions. Note: error bars represent $95 \%$ confidence intervals.

\section{Discussion}

Our goals were to investigate beliefs about connectedness with nature and human exceptionalism in the context of a hypothetical urban waterway, to examine the degree to which these beliefs influenced stewardship and investment, and to ascertain the impact of framing on any of these constructs. To do so, we presented participants with a brief scenario describing an urban waterway as natural or artificial, and pollution of the waterway (and the ability of the waterway and surrounding wetlands to remove this pollution) as having global or local consequences. After reading the scenario, participants answered a series of questions about beliefs, stewardship, and investment.

\subsection{What Do People Believe about the Relationship between Humans and Urban Waterways?}

In general, participants believed that humans and urban waterways strongly impacted each other. Participants' ratings of human impact on the river were high, demonstrating an acknowledgement of the influence of humans on their surrounding land-water envi- 
ronments, even in urban settings. Ratings of the river's impact on humans were also high, suggesting a corresponding acknowledgement that our natural environment influences us.

Nevertheless, responses demonstrated human exceptionalism in several ways. Ratings of human impact on the river were higher than ratings of the river's impact on humans, and more than twice as many people asymmetrically rated humans' impact on rivers higher, reflecting a belief that humans have a disproportionate impact on their environment, rather than a reciprocal mutual influence. This pattern aligns with other exceptionalist findings demonstrating the belief that people have more impact on nature than vice-versa, for example, believing that humans can cause climate change, but will be uniquely immune from the effects of climate change [27,28]. Moreover, beliefs about human impact were a stronger predictor of beliefs about connectedness than beliefs about the river's impact, suggesting that "connectedness" was perceived largely in terms of humans' unidirectional impact on other organisms, rather than our dependence on them or mutuality.

In many ways, these asymmetrical relationships are diagnostic of continually evolving views of the role of humans in nature in majority populations in the U.S. Whereas earlier environmentalists focused primarily on the protection of nature from the impacts of humans (for example, Rachel Carson's 1962 Silent Spring [62]), more modern views envision people as part of a coupled human-natural ecosystem where feedbacks occur between human behavior and the resulting effects of ecosystem services on people [63,64]. Even more recently, relativistic approaches capture these relationships in concepts such as Nature's Contribution to People or Social-Ecological Systems [65]. However, despite these evolving views in academic circles, it is not always clear as to the degree to which these ideas permeate the general public $[66,67]$. Our results suggest that there is still a lack of understanding of these feedback loops, and especially of the value of ecosystems to human well-being [68].

\subsection{How Are Beliefs Related to Environmental Investment or Stewardship?}

Human exceptionalism predicted environmental investment: the more a person held exceptionalist beliefs, the less likely they were to endorse investing time and money in restoration efforts. This finding importantly demonstrates that exceptionalist beliefs could have implications for environmentally relevant attitudes and behaviors, adding to other findings demonstrating the inverse relationship between human exceptionalism and proenvironmentalism (e.g., $[27,28]$ ). Although we cannot make causal inferences, it also raises the possibility that interventions aimed at reducing exceptionalist thinking might also impact willingness to invest in environmental initiatives.

Investment also increased with reported proximity to water. This relationship could be interpreted through the lens of psychological distance, suggesting that reduced perceived physical distance to a waterway is associated with a stronger desire for investment in conservation. In conjunction, the finding that psychological distance, as measured by self-reported proximity, predicted investment, but not stewardship, replicates the findings of Larson and Santelman (2007) [51], and underscores the complex relationship of psychological distance to environmental attitudes. Adding to this complexity, investment was unrelated to perceived ecological connectedness. This suggests that perceived proximity to water provided unique explanatory value towards investing time and money in river restoration, beyond increasing feelings of ecological connectedness.

In contrast to investment, environmental stewardship was unrelated to human exceptionalism or proximity to water, but was positively predicted by ecological connectedness. The more one believed that humans are ecologically connected to other living things, the more one also supported environmental stewardship (specifically protective laws and initiatives, human responsibility, and prioritization of river restoration). This finding adds to growing evidence that ecological connectedness positively impacts pro-environmentalism (e.g., $[12,69])$, expanding this account to clarify that this effect provides unique explanatory value separate from the related constructs of human exceptionalism and psychological distance to similar ecosystems (e.g., waterways). Bearing in mind the causal caveat mentioned 
above, this finding nevertheless suggests that efforts aimed at increasing perceptions of ecological connectedness may, in turn, have positive effects on environmental stewardship.

\subsection{How Does Framing Influence Beliefs, Investment, and Stewardship?}

To examine the degree to which framing impacts environmental beliefs and attitudes, we manipulated whether the urban river described in our brief vignette had natural (preexisting the city) or artificial (human-made with the intention of funneling the city's runoff) origins, and whether the consequences of the river's ecological impact was described in local (serving as a drainage system that removes waste from the city) or global (filtering the city's polluted run-off water before the water enters the ocean) terms. Describing the river's ecological impact in local terms resulted in lower human exceptionalism than describing this in global terms, or when impact wasn't mentioned at all. Moreover, this reduction was due to an increase in the perceived impact of the river on the people living in the city. The artificial-natural manipulation had no effect on exceptionalism, suggesting that the distinction between green and gray infrastructure may not have been salient to our participants.

This finding is consistent with previous work demonstrating the efficacy of emphasizing local implications of ecological issues when trying to influence attitudes (e.g., [46,47]). It also extends that finding by demonstrating that emphasizing local impacts of an urban waterway can increase the degree to which that river is perceived to impact residents, and thereby reduce asymmetries in the perceived impact of humans and the waterway associated with exceptionalist thinking. Thus, framing has the potential to impact beliefs about relations between humans and the ecosystems they inhabit. We believe this evidence supports the position articulated by Brügger et al. (2015) [40] that "proximizing" (i.e., stressing local consequences) changes mental representations and the basis for decision-making, rather than directly impacting behavioral motivation.

\subsection{Implications for Stakeholder Engagement}

In keeping with the theme of this special issue, we see important implications of this work for stakeholder engagement. The vast majority of environmental problems require understanding and engaging stakeholders, yet this latter task is notoriously difficult [70]. One of the most common challenges and pitfalls of previous stakeholder engagement efforts is an oversimplification of the links among environmental awareness, concern, and behavior [71,72]. Our study evaluates and discusses the importance of several key influences on stakeholder engagement.

We have shown that beliefs about human exceptionalism-which, in our sample, were common regarding urban waterways-and ecological connectedness are important predictors of environmental investment and stewardship. This demonstrates the larger point that how one conceptualizes the world and one's place in it plays an important role in how one chooses to engage with the world. Conversely, in order to influence environmental behavior, we need to understand environmental beliefs and cognition [73]. By understanding stakeholders' beliefs about human exceptionalism, ecological connectedness, psychological distance, and other relevant dimensions, we can better craft effective ways to engage and motivate them [70]. For example, if stakeholders hold beliefs that are contradictory to investment and stewardship, it may be helpful to directly address these beliefs to undermine their maleffects [74].

Though others have also shown that the way in which information is presented can impact stakeholder beliefs [75,76], our results also show that considering individual-level beliefs like human exceptionalism is important. Emphasizing local consequences increased the degree to which a river was thought to impact people in the surrounding city, thereby decreasing human exceptionalism. This suggests that proximizing ecological information has the potential to reduce exceptionalist thinking. And although framing had no direct effect on investment, reducing exceptionalist thinking may have the indirect effect of increasing investment. 
Finally, by demonstrating the importance of beliefs and their potential for plasticity, our findings also emphasize the importance of understanding differences in beliefs between stakeholder groups, which might represent both a source of conflict and a potential path to broader and more successful engagement.

\subsection{Limitations and Future Directions}

Several limitations of the current study set the stage for future follow-up work. One involves measures: for example, our measure of human exceptionalism was based on responses to two items; it would be useful to develop more extensive and converging measures of human exceptionalism. Likewise, our measure of ecological connectedness was based on responses to a single item; future work could employ converging validated measures (e.g., $[29,33,77])$. On another front, although the use of hypothetical scenarios allowed us to survey a broad sample of participants, and indeed, we found framing effects for hypothetical vignettes, this approach is still relatively abstract and removed from lived experience. Going forward, it would be informative to ask comparable questions about real waterways to people living along those waterways, especially given the importance of engaging local stakeholders in climate adaptation and environmental management [78,79]. Similar patterns of results would bolster the generalizability of our findings, whereas different results might highlight the place-based nature of such beliefs. Relatedly, our sample is a general national one of English-speaking US residents. Future work could target specific subgroups of stakeholders to examine how relations among these constructs might vary as a function of different goals and perceptions. Another way to extend this work would be to examine different ecosystems. We focus on urban waterways, due to our own location in Boston, but our approach could be applied to a wide range of socio-ecological land-water systems, as well as other types of ecosystems. Again, such work would inform the degree to which the relations we discuss are ecosystem-specific or more general.

Further, whereas we set out to explore individual attitudes and behaviors, future research should explore of the role of key demographic factors (e.g., education level, region of residence, urban versus rural location) on these beliefs. If reliable links are found between demographics and beliefs, these stakeholder beliefs could be more accurately predicted from more readily accessible information. This could permit belief-focused tailoring of information to engage stakeholders.

Finally, we demonstrate that although proximizing can "move the needle" on human exceptionalism, and that human exceptionalism is a predictor of investment, framing had no direct effect on investment or stewardship. Future work should explore the causal relations among these constructs, with an eye toward developing interventions aimed at effectively enhancing perceived ecological connectedness and/or reducing human exceptionalism. One way to do so might be to encourage stakeholders to explicitly include humans in their mental models of interrelations among components for a given environmental issue (e.g., $[27,28])$. Another approach might involve the use of immersive art installations or experiences, or to decrease psychological distance (e.g., $[80,81])$.

\section{Conclusions}

These results suggest that beliefs such as human exceptionalism and ecological connectedness are an important component of people's understanding of human-land-water interactions in an urban context. They demonstrate that these beliefs are associated with both investment and stewardship. And they demonstrate that psychological distance is related to investment, and that proximizing (by emphasizing local implications) decreases exceptionalist thinking. More generally, these results underscore the need to understand the conceptual frameworks with which humans make sense of the world around them in order to facilitate stakeholder engagement in finding effective solutions to environmental challenges arising from the complex interactions of land, water, and human society. 
Supplementary Materials: The following supplementary materials are available online at https: / / www.mdpi.com/article/10.3390/land10121293/s1: Full Study Vignettes, Extended Participant Demographics, Confirmatory Factor Analysis for Investment and Stewardship Measures.

Author Contributions: Conceptualization, J.D.C., N.B., B.H., K.E. and D.A.; Methodology, J.D.C., N.B., B.H., K.E. and D.A.; Data Collection, N.B.; Data Analysis, J.D.C. and N.B.; Original Draft Preparation, J.D.C., N.B., B.H. and S.B.S.; Review \& Editing, J.D.C., N.B., B.H., S.B.S., K.E. and D.A. All authors have read and agreed to the published version of the manuscript.

Funding: This research was funded by an internal TIER 1 interdisciplinary grant from the Office of the Provost, Northeastern University.

Institutional Review Board Statement: The study was conducted according to the guidelines of the Declaration of Helsinki, and approved by the Institutional Review Board of Northeastern University (protocol IRB\# 18-04-20, approved 2 May 2018).

Informed Consent Statement: Informed consent was obtained from all subjects involved in the study.

Data Availability Statement: Dataset is available from the corresponding author.

Acknowledgments: We are grateful to Kyleigh Watson, Kelly Marchese, Daniela Ras, Finn Payne, and Francis Choi for their valuable contributions to the research reported here.

Conflicts of Interest: The authors declare no conflict of interest.

\section{References}

1. Reed, M.S.; Vella, S.; Challies, E.; de Vente, J.; Frewer, L.; Hohenwallner-Ries, D.; Huber, T.; Neumann, R.K.; Oughton, E.A.; Sidoli del Ceno, J.; et al. A theory of participation: What makes stakeholder and public engagement in environmental management work? Restor. Ecol. 2018, 26, S7-S17. [CrossRef]

2. Ferreira, V.; Barreira, A.P.; Loures, L.; Antunes, D.; Panagopoulos, T. Stakeholders' engagement on nature-based solutions: A systematic literature review. Sustainability 2020, 12, 640. [CrossRef]

3. Brugger, A.; Morton, T.A.; Dessai, S. "Proximising" climate change reconsidered: A construal level theory perspective. J. Environ. Psychol. 2016, 46, 125-142. [CrossRef]

4. Gray, M.; Micheli, E.; Comendant, T.; Merenlender, A. Climate-Wise habitat connectivity takes sustained stakeholder engagement. Land 2020, 9, 413. [CrossRef]

5. Tompkins, E.L.; Few, R.; Brown, K. Scenario-based stakeholder engagement: Incorporating stakeholders preferences into coastal planning for climate change. J. Environ. Manag. 2008, 88, 1580-1592. [CrossRef] [PubMed]

6. Cutler, M.J.; Marlon, J.R.; Howe, P.D.; Leiserowitz, A. The influence of political ideology and socioeconomic vulnerability on perceived health risks of heat waves in the context of climate change. Weather Clim. Soc. 2018, 10, 731-746. [CrossRef]

7. Jurjonas, M.; Seekamp, E. A commons before the sea:' climate justice considerations for coastal zone management. Clim. Dev. 2020, 12, 199-203. [CrossRef]

8. Komatsu, H.; Rappleye, J.; Silova, I. Culture and the Independent Self: Obstacles to environmental sustainability? Anthropocene 2019, 26, 100198. [CrossRef]

9. Lee, T.M.; Markowitz, E.M.; Howe, P.D.; Ko, C.-Y.; Leiserowitz, A.A. Predictors of public climate change awareness and risk perception around the world. Nat. Clim. Chang. 2015, 5, 1014-1020. [CrossRef]

10. Meadows, D.H. Thinking in Systems: A Primer; Chelsea Green Publishing: White River Junction, VT, USA, 2008.

11. Ban, N.C.; Picard, C.R.; Vincent, A.C.J. Comparing and integrating community-based and science-based approaches to prioritizing marine areas for protection. Conserv. Biol. 2009, 23, 899-910. [CrossRef]

12. Schultz, P.W. Inclusion with nature: The psychology of human-nature relations. In Psychology of Sustainable Development; Schmuck, P., Schultz, P.W., Eds.; Springer: New York, NY, USA, 2002; pp. 61-78.

13. Davis, A.; Taylor, C.E.; Martin, J.M. Are pro-ecological values enough? Determining the drivers and extent of participation in citizen science programs. Hum. Dimens. Wildl. 2017, 24, 501-514. [CrossRef]

14. McKinley, D.C.; Miller-Rushing, A.J.; Ballard, H.L.; Bonney, R.; Brown, H.; Cook-Patton, S.C.; Evans, D.M.; French, R.A.; Parrish, J.K.; Phillip, T.B.; et al. Citizen science can improve conservation science, natural resource management, and environmental protection. Biol. Conserv. 2017, 208, 15-28. [CrossRef]

15. Scyphers, S.B.; Gouhier, T.C.; Grabowski, J.H.; Beck, M.W.; Mareska, J.; Powers, S.P. Natural shorelines promote the stability of fish communities in an urbanized coastal system. PLoS ONE 2015, 10, e0118580.

16. Biggs, D.; Abel, N.; Knight, A.T.; Leitch, A.; Langston, A.; Ban, N.C. The implementation crisis in conservation planning: Could "mental models" help? Conserv. Lett. 2011, 4, 169-183. [CrossRef]

17. Nielsen, K.S.; Clayton, S.; Stern, P.C.; Dietz, T.; Capstick, S.; Whitmarsh, L. How psychology can help limit climate change. Am. Psychol. 2021, 76, 130-144. [CrossRef] 
18. Coley, J.D.; Tanner, K. Relations between intuitive biological thinking and biological misconceptions in biology majors and nonmajors. CBE Life Sci. Educ. 2015, 14, ar8. [CrossRef]

19. Coley, J.D.; Tanner, K.D. Common origins of diverse misconceptions: Cognitive principles and the development of biology thinking. CBE Life Sci. Educ. 2012, 11, 209-215. [CrossRef]

20. Danielson, K.I.; Tanner, K.D. Investigating undergraduate science students' conceptions and misconceptions of ocean acidification. CBE Life Sci. Educ. 2015, 14, ar29. [CrossRef]

21. Shtulman, A. How lay cognition constrains scientific cognition. Philos. Compass 2015, 10, 785-798. [CrossRef]

22. Cuzzolino, M.P.; Grotzer, T.A.; Tutwiler, M.S.; Torres, E.W. An agentive focus may limit learning about complex causality and systems dynamics: A study of seventh graders' explanations of ecosystems. J. Res. Sci. Teach. 2019, 56, 1083-1105. [CrossRef]

23. Coley, J.D. The human animal: Developmental changes in judgments of taxonomic and psychological similarity among humans and other animals. Cogn. Brain Behav. 2007, 11, 733-756.

24. Gee, H. The Accidental Species: Misunderstandings of Human Evolution; University of Chicago Press: Chicago, IL, USA, 2013.

25. Shannon, L. Chapter Seven. Invisible parts: Animals and the Renaissance anatomies of human exceptionalism. In Animal Encounters; Rossini, M., Tyler, T., Eds.; Brill: Boston, MA, USA, 2009; pp. 135-157.

26. Fux, M.; de Nesnera, K.; Xu, Y.; Betz, N.; Leffers, J.; Tanner, K.; Coley, J.D. Demonstrating contingency between intuitive biological reasoning and persistent biological misconceptions across levels of academic expertise. Poster presented at the 30th Annual Convention of the Association for Psychological Science, San Francisco, CA, USA, 24-17 May 2018.

27. Betz, N. Anthropic thinking about global climate change. In Department of Psychology; Northeastern University: Boston, MA, USA, 2021.

28. Betz, N.; Coley, J.D. Human exceptionalist thinking about climate change. OSF Prepr. 2021. [CrossRef]

29. Mayer, F.S.; Frantz, C.M. The connectedness to nature scale: A measure of individuals' feeling in community with nature. J. Environ. Psychol. 2004, 24, 503-515. [CrossRef]

30. Mayer, F.S.; Frantz, C.M.; Bruehlman-Senecal, E. Why Is nature beneficial? The role of connectedness to nature. Environ. Behav. 2009, 41, 607-643. [CrossRef]

31. Medin, D.L.; Bang, M. The cultural side of science communication. Proc. Natl. Acad. Sci. USA 2014, 111, 13621-13626. [CrossRef] [PubMed]

32. Frantz, C.M.; Mayer, F.S. The importance of connection to nature in assessing environmental education programs. Stud. Educ. Eval. 2014, 41, 85-89. [CrossRef]

33. Nisbet, E.K.; Zelenski, J.M.; Murphy, S.A. The nature relatedness scale: Linking individuals' connection with nature to environmental concern and behavior. Environ. Behav. 2009, 41, 715-740. [CrossRef]

34. Clayton, S.; Luebke, J.F.; Saunders, C.; Matiasek, J. Connecting to nature at the zoo: Implications for responding to climate change. Environ. Educ. Res. 2014, 20, 460-475. [CrossRef]

35. Denton, H.; Aranda, K. The wellbeing benefits of sea swimming. Is it time to revisit the sea cure? Qual. Res. Sport Exerc. Health 2020, 12, 647-663. [CrossRef]

36. Alcock, I.; White, M.P.; Pahl, S.; Duarte-Davidson, R.; Fleming, L.E. Associations between pro-environmental behaviour and neighbourhood nature, nature visit frequency and nature appreciation: Evidence from a nationally representative survey in England. Environ. Int. 2020, 136, 105441. [CrossRef]

37. De Ville, N.V.; Tomasso, L.P.; Stoddard, O.P.; Wilt, G.E.; Horton, T.H.; Wolf, K.L.; Brymer, E.; Kahn, P.H., Jr.; James, P. Time spent in nature is associated with Increased pro-environmental attitudes and behaviors. Int. J. Environ. Res. Public Health 2021, 18, 7498. [CrossRef]

38. Liberman, N.; Trope, Y.; Stephan, E. Psychological Distance. In Social Psychology: Handbook of Basic Principles; Kruglanski, A.W., Higgins, E.T., Eds.; The Guilford Press: New York, NY, USA, 2007; pp. 353-381.

39. McDonald, R.I.; Chai, H.Y.; Newell, B.R. Personal experience and the 'psychological distance' of climate change: An integrative review. J. Environ. Psychol. 2015, 44, 109-118. [CrossRef]

40. Bruügger, A.; Dessai, S.; Devine-Wright, P.; Morton, T.A.; Pidgeon, N.F. Psychological responses to the proximity of climate change. Nat. Clim. Chang. 2015, 5, 1031-1037. [CrossRef]

41. Duan, R.; Zwickle, A.; Takahashi, B. Refining the application of construal level theory: Egocentric and nonegocentric psychological distances in climate change visual communication. Environ. Commun. 2021, in press. [CrossRef]

42. Pong, V. Global versus local framing of the issue of food waste: The role of Identification With All Humanity and the implications for climate change communication. Asian J. Soc. Psychol. 2021, 24, 221-231. [CrossRef]

43. Levin, I.P.; Schneider, S.; Gaeth, G.J. All frames are not created equal: A typology and critical analysis of framing effects. Organ. Behav. Hum. Decis. Process. 1998, 76, 149-188. [CrossRef] [PubMed]

44. Tversky, A.; Kahneman, D. The framing of decisions and the psychology of choice. Science 1981, 211, 453-458. [CrossRef]

45. Hine, D.W.; Phillips, W.J.; Cooksey, R.; Reser, J.P.; Nunn, P.; Marks, A.D.G.; Loi, N.M.; Watt, S.E. Preaching to different choirs: How to motivate dismissive, uncommitted, and alarmed audiences to adapt to climate change? Glob. Environ. Chang. 2016, 36, 1-11. [CrossRef]

46. Altinay, Z. Visual communication of climate change: Local framing and place attachment. Coast. Manag. 2017, 45, 293-309. [CrossRef] 
47. Evans, L.; Milfont, T.L.; Lawrence, J. Considering local adaptation increases willingness to mitigate. Glob. Environ. Chang. 2014, 25, 69-75. [CrossRef]

48. Schoenefeld, J.J.; McCaule, M.R. Local is not always better: The impact of climate information on values, behavior and policy support. J. Environ. Stud. Sci. 2016, 6, 724-732. [CrossRef]

49. Spence, A.; Pidgeon, N. Framing and communicating climate change: The effects of distance and outcome frame manipulations. Glob. Environ. Chang. 2010, 20, 656-667. [CrossRef]

50. Milfont, T.L.; Evans, L.; Sibley, C.G.; Ries, J.; Cunningham, A. Proximity to coast is linked to climate change belief. PLoS ONE 2014, 9, e103180. [CrossRef]

51. Larson, K.L.; Santelmann, M.V. An analysis of the relationship between residents' proximity to water and attitudes about resource protection. Prof. Geogr. 2007, 59, 316-333. [CrossRef]

52. Wilkins, E.J.; Sinclair, W.; Miller, H.M.; Schuster, R.M. Does proximity to wetlands matter? A landscape-level analysis of the influence of local wetlands on the public's concern for ecosystem services and conservation involvement. Wetlands 2019, 39, 1271-1280. [CrossRef]

53. Zheng, H.; Li, Y.; Robinson, B.E.; Liu, G.; Ma, D.; Wang, F.; Lu, F.; Ouyang, Z.; Daily, G.C. Using ecosystem service trade-offs to inform water conservation policies and management practices. Front. Ecol. Environ. 2016, 14, 527-532. [CrossRef]

54. LaPointe, M.; Cumming, G.S.; Gurney, G. Comparing ecosystem service preferences between urban and rural dwellers. Bioscience 2019, 69, 108-116. [CrossRef]

55. Duarte, C.M.; Dennison, W.C.; Orth, R.J.W.; Carruthers, T.J.B. The charisma of coastal ecosystems: Addressing the imbalance. Estuaries Coasts 2008, 31, 233-238. [CrossRef]

56. Strain, E.M.A.; Alexander, K.A.; Kienker, S.; Morris, R.; Jarvis, R.; Coleman, R.; Bollard, B.; Firth, L.B.; Knights, A.M.; Grabowski, J.H.; et al. Urban blue: A global analysis of the factors shaping people's perceptions of the marine environment and ecological engineering in harbours. Sci. Total Environ. 2019, 658, 1293-1305. [CrossRef]

57. Kellert, S.R.; Case, D.J.; Escher, D.; Witter, D.J.; Mikels-Carrasco, J.; Seng, P.T. The Nature of Americans: Disconnection and Recommendations for Reconnection. The Nature of Americans Report; D.J. Case \& Associates: Mishawaka, IN, USA, 2017.

58. Firth, L.B.; Airoldi, L.; Bulleri, F.; Challinor, S.; Chee, S.-Y.; Evans, A.J.; Hanley, M.E.; Knights, A.M.; O'Shaughnessy, K.; Thompson, R.C.; et al. Greening of grey infrastructure should not be used as a Trojan horse to facilitate coastal development. J. Appl. Ecol. 2020, 57, 1762-1768. [CrossRef]

59. Kapetas, L.; Fenner, R. Integrating blue-green and grey infrastructure through an adaptation pathways approach to surface water flooding. Philos. Trans. R. Soc. A 2020, 378, 20190204. [CrossRef]

60. Tian, Y.; Wu, H.; Zhang, G.; Wang, L.; Zheng, D.; Li, S. Perceptions of ecosystem services, disservices and willingness-to-pay for urban green space conservation. J. Environ. Manag. 2020, 260, 110140. [CrossRef] [PubMed]

61. Venkataramanan, V.; Packman, A.I.; Peters, D.R.; Lopez, D.; McCuskey, D.J.; McDonald, R.I.; Miller, W.M.; Young, S.L. A systematic review of the human health and social well-being outcomes of green infrastructure for stormwater and flood management. $J$. Environ. Manag. 2019, 246, 868-880. [CrossRef] [PubMed]

62. Carson, R. Silent Spring; Houghton Mifflin: Boston, MA, USA, 1962.

63. Carter, N.H.; Viña, A.; Hull, V.; McConnell, W.J.; Axinn, W.; Ghimire, D.; Liu, J. Coupled human and natural systems approach to wildlife research and conservation. Ecol. Soc. 2014, 19, 43. [CrossRef]

64. Liu, J.; Dietz, T.; Carpenter, S.R.; Taylor, W.W.; Alberti, M.; Deadman, P.; Redman, C.; Pell, A.; Folke, C.; Ouyang, Z.; et al. Coupled human and natural systems: The evolution and applications of an integrated framework. Ambio 2021, 50, 1778-1783. [CrossRef]

65. Díaz, S.; Pascual, U.; Stenseke, M.; Martìn-Lòpez, B.; Watson, R.T.; Molnàr, Z.; Hill, R.; Chan, K.A.M.; Baste, I.A.; Brauman, K.A.; et al. Assessing nature's contributions to people. Science 2018, 359, 270-272. [CrossRef]

66. Asah, S.T.; Guerry, A.D.; Blahna, D.J.; Lawler, J.J. Perception, acquisition and use of ecosystem services: Human behavior, and ecosystem management and policy implications. Ecosyst. Serv. 2014, 10, 180-186. [CrossRef]

67. DeLorme, D.E.; Stephens, S.H.; Collini, R.C.; Yoskowitz, D.W.; Hagen, S.C. Communicating and understanding ecosystem services assessment with coastal stakeholders: Obstacles and opportunities. Front. Commun. 2021, 6, 78. [CrossRef]

68. Karimi, A.; Yazdandad, H.; Fagerholm, N. Evaluating social perceptions of ecosystem services, biodiversity, and land management: Trade-offs, synergies and implications for landscape planning and management. Ecosyst. Serv. 2020, 45, 101188. [CrossRef]

69. Ahn, S.J.G.; Bostick, J.; Ogle, E.; Nowak, K.L.; McGillicuddy, K.T.; Bailenson, J.N. Experiencing nature: Embodying animals in immersive virtual environments increases inclusion of nature in self and involvement with nature. J. Comput. Mediat. Commun. 2016, 21, 399-419. [CrossRef]

70. Reddy, S.M.W.; Montambault, J.; Masuda, Y.T.; Keenan, E.; Butler, W.; Fisher, J.R.B.; Asah, S.T.; Gneezy, A. Advancing conservation by understanding and influencing human behavior. Conserv. Lett. 2017, 10, 248-256. [CrossRef]

71. Heberlein, T.A. Attitudes and environmental management. J. Soc. Issues 1989, 45, 37-57. [CrossRef]

72. Stern, P.C. New environmental theories: Toward a coherent theory of environmentally significant behavior. J. Soc. Issues 2000, 56, 407-424. [CrossRef]

73. Smith, J.W.; Davenport, M.A.; Anderson, D.H.; Leahy, J.E. Place meanings and desired management outcomes. Landsc. Urban Plan. 2011, 101, 359-370. [CrossRef]

74. Chapin, F.S.; Carpenter, S.R.; Kofinas, G.P.; Folke, C.; Abel, N.; Clark, W.C.; Olsson, P.; Smith, D.M.S.; Walker, B.; Young, O.R.; et al. Ecosystem stewardship: Sustainability strategies for a rapidly changing planet. Trends Ecol. Evol. 2010, 25, 241-249. [CrossRef] 
75. Krantz, S.A.; Monroe, M.C. Message framing matters: Communicating climate change with forest landowners. J. For. 2016, 114, 108-115. [CrossRef]

76. Stevenson, K.T.; King, T.L.; Selm, K.R.; Peterson, M.N.; Monroe, M.C. Framing climate change communication to prompt individual and collective action among adolescents from agricultural communities. Environ. Educ. Res. 2018, 24, 365-377. [CrossRef]

77. Schultz, P.W. The structure of environmental concern: Concern for self, other people, and the biosphere. J. Environ. Psychol. 2001, 21,327-339. [CrossRef]

78. Harlan, S.L.; Sarango, M.J.; Mack, E.A.; Stephens, T.A. A survey-based assessment of perceived flood risk in urban areas of the United States. Anthropocene 2019, 28, 100217. [CrossRef]

79. Scyphers, S.B.; Beck, M.W.; Furman, K.L.; Haner, J.; Keeler, A.G.; Landry, C.E.; O’Donnell, K.L.; Webb, B.M.; Grabowski, J.H. Designing effective incentives for living shorelines as a habitat conservation strategy along residential coasts. Conserv. Lett. 2020, 13, e12744. [CrossRef]

80. Breves, P.; Heber, V. Into the wild: The effects of $360^{\circ}$ immersive nature videos on feelings of commitment to the environment. Environ. Commun. 2020, 14, 332-346. [CrossRef]

81. Breves, P.; Schramm, H. Bridging psychological distance: The impact of immersive media on distant and proximal environmental issues. Comput. Hum. Behav. 2021, 115, 106606. [CrossRef] 